\title{
Morphophysiological profile of Jatropha curcas L. fruits and seeds maturation ${ }^{1}$
}

\section{Perfil morfofisiológico da maturação de frutos e sementes de Jatropha curcas L.}

\author{
Cristiane Dantas de Brito $^{2}$; Marta Bruno Loureiro ${ }^{3}$; Aliomar Pacheco de Souza \\ Junior'; Luzimar Gonzaga Fernandez ${ }^{3}$; Renato Delmondez de Castro ${ }^{3 *}$
}

\begin{abstract}
Jatropha curcas L. (Euphorbiaceae), known as physic nut, is an oil seed species suitable as feedstock for biodiesel production, among other possible industrial applications. It is also considered tolerant to water restriction and is thus suitable for cultivation in semi-arid regions. However, the lack of uniformity in fructification and seed maturation hinders the harvest and processing of fruits and seeds and the yields from both oil and seed, as well as obtaining seed lots with good physiological quality as propagule. Thus, the aim of this study was to characterise the physiological profile during the development and maturation of $J$. curcas seeds and to identify the best time to harvest the fruits and seeds based on morphological and physiological aspects. Fruit and seed development was monitored and the fruits were harvested at the end of the maturation phase. Then, they were visually classified in six distinct stages of maturation based on the size and colour of the exocarp, whereas the seeds were classified into 13 distinct stages based on the appearance of the fruit and colour of the tegument. The overall analysis of the parameters indicated that the best harvest time was when the fruits were brown and dry and the seeds presented maximum dry matter accumulation, lower moisture content, the highest germination and vigour, higher lipid content and stable length and width dimensions. Whereas these parameters are related to physiological maturation in $J$. curcas seeds.
\end{abstract}

Key words: Physic nut, dry weight, germination, physiological maturity, oil content

\section{Resumo}

Jatropha curcas L. (Euphorbiaceae) conhecida como pinhão manso, possui sementes oleaginosas adequadas como matéria-prima para a produção de biodiesel, dentre outras aplicações industriais. É uma espécie tolerante à restrição hídrica e por isso apropriada ao cultivo em regiões semiáridas. As irregularidades na frutificação e maturação dificultam a colheita e o processamento de frutos e sementes, o rendimento em sementes e óleo, assim como a obtenção de lotes de sementes com boa qualidade fisiológica para fins de propágulo. O objetivo deste trabalho consistiu em caracterizar o perfil fisiológico durante a maturação de sementes de pinhão manso e identificar a melhor época de colheita baseandose em aspectos morfológicos e fisiológicos. O desenvolvimento dos frutos e sementes foi monitorado no campo e, ao final da safra, os frutos foram colhidos numa única etapa e classificados visualmente em seis estádios distintos de desenvolvimento e maturação, conforme coloração do exocarpo. As

\footnotetext{
1 Parte da tese de Doutorado em Recursos Genéticos Vegetais do primeiro autor, Universidade Estadual de Feira de Santana, UEFS, Feira de Santana, BA, Brasil.

$2 \mathrm{Dr}^{\mathrm{a}}$ em Recursos Genéticos Vegetais, UEFS, Feira de Santana, BA, Brasil. E-mail: crisbrichta@gmail.com

3 Profs. Drs., Universidade Federal da Bahia, UFBA, Salvador, BA, Brasil. E-mail: brunoloureiro70@gmail.com; luzimar@ufba. br; luzimargonzaga@gmail.com; renatodelmondez@ufba.br

4 Discente do Curso de Graduação em Biotecnologia, UFBA, Salvador, BA, Brasil. E-mail: aliomar.psj@gmail.com

* Author for correspondence
} 
sementes foram classificadas em treze estádios baseando-se no aspecto do fruto e na coloração da testa. Os parâmetros analisados indicam que a melhor época de colheita é quando os frutos estão secos e com coloração marrom, e as sementes apresentaram máximo acúmulo de matéria seca, menor teor de umidade, maior germinação e vigor, maior teor de lipídeos e dimensões estabilizadas em comprimento e largura, parâmetros estes relacionados com o ponto de maturidade fisiológica para as sementes de pinhão manso.

Palavras-chave: Pinhão manso, massa seca, germinação, maturidade fisiológica, teor de óleo

\section{Introduction}

The life cycle of higher plants include seed development, followed by germination and postgermination development. These steps are marked by specific physiological events related to changes in moisture content, fresh weight, dry weight, and distinct patterns of gene expression, as well as the establishment of the fundamental plant architecture, such as histogenesis, organogenesis and morphogenesis (BEWLEY; BLACK, 1994; TAIZ; ZEIGER, 2009).

Seed embryogenesis is characterised by rapid and successive cell divisions and histodifferentiation. In this process, a single cell is transformed into a multicellular body. The phase of seed maturation, on the other hand, is associated with reserve deposition and cell expansion. In orthodox seeds, there is a drying or desiccation phase characterised by a rapid decline of fresh weight, making these seeds tolerant to desiccation (BEWLEY; BLACK, 1994).

The maximum seed quality, expressed by germination and vigour, is also associated with maximum accumulation of dry weight during development (physiological maturity). This point marks suspension of metabolite transport from the phloem to the seed, and in some cases, specific changes occur in the tissues that attach the seed to the mother plant (EGLI, 1998; CASTRO; HILHORST, 2004).

Jatropha curcas L. occurs naturally in the semiarid northeastern part of Brazil and countries of the equatorial Americas. However, although the species has not been fully domesticated yet, it already stands out for the potential of its oleaginous seeds, as well as for its apparent hardiness and tolerance to conditions of abiotic stress, and maybe even to conditions of biotic stress (SATURNINO et al., 2005). At present, this culture is considered to be yet another option for agriculture in the Brazilian northeast, as it constitutes a viable crop for obtaining oil as raw material for the manufacture of biodiesel, with a minimum yield of two tons of seeds per hectare (DRUMMOND et al., 2008). J. curcas seeds have a high oil content of about $55 \%$, and are rich in high quality fatty acids. Their use for biodiesel production may contribute to reducing the emission of greenhouse gases through partial substitution of fossil fuels (OPENSHAW, 2000; JONGSCHAAP et al., 2007).

The life cycle of the species varies according to the type of reproduction, which can be sexual or vegetative. In general, plants grown from seeds are more resistant and have greater longevity, reaching a productive age after four years, while those from stakes have a shorter and less vigorous root system, and although production begins after 10 months, it only reaches fullness after two years. When obtained from seeds and in good production condition, the longevity of $J$. curcas can be 30-40 years, and may even reach up to 50 years (CORTESÃO, 1956; PEIXOTO, 1973; ACHTEN et al., 2010).

The interaction of environmental and intrinsic factors affects the maturation of seeds and fruits and involves significant changes in the biochemical composition, the amount of dry matter, moisture content, size, germination and vigour of the seeds (DELOUCHE, 1980; DE RON et al., 2004). The association of morphological and physiological markers is a reliable way to identify the different stages of development (MICHELANGELI et al., 
2013). The maximum quality of a seed depends on the current maturity stage of the embryo and endosperm, and can occur before or after the physiological maturity point (CARVALHO; NAKAGAWA, 2000; DIAS, 2001).

Taking into consideration the fact that the seed is the end (or initial) product, and the carrier of the genetic characteristics of the plant, its physiological features as a propagule, and its biochemical characteristics as an end product, this study aims to characterise the formation process of $J$. curcas seeds through the analysis of physiological and biochemical changes, as well as morphological aspects, during the ripening of the seed.

\section{Material and Methods}

The biological material used in this work was produced in the experimental field of the Company for Agricultural Development of Bahia (EBDA), located in the municipality of Alagoinhas in the state of Bahia (latitude $12^{\circ} 08^{\prime}-12^{\circ} 10^{\prime} \mathrm{S}$, longitude and $\left.3826^{\circ}-3830^{\prime} \mathrm{W}\right)$. The tests were conducted at the Laboratory for Biochemistry, Biotechnology and Bioproducts (LBBB) of the Federal University of Bahia (UFBA). Initially, flowering, as well as fruit and seed development, was monitored through weekly visits to the field. To this end, the inflorescences containing female flower buds were marked with coloured tape and identified with paper labels, prior to the occurrence of anthesis. The resulting fruits were monitored during their development and were collected manually at once during the last step of monitoring in the field. At that moment, they presented different stages of maturation, and were thus classified based on size and colour. After the harvest, the seeds were extracted from the fruits and were classified based on the colouring of the testa, which was reserved for conducting the tests.

The morphometric analyses were performed by measuring fruits and seeds at different stages of development. Measurements were taken using a digital calliper (Jomarca) with an accuracy of 0.01 $\mathrm{mm}$. The fruits were measured by length (distance from stalk to opposite side) and width (median region). For seeds, the following dimensions were analysed: length (measured from apex to hilum/ caruncle to the opposite side), width and thickness (median region). To this end, four replications of 25 fruits/seeds were used, with the results expressed in millimetres.

To determine the moisture content, four repetitions were used of approximately $5 \mathrm{~g}$ of seeds, previously cut in four parts with a blade. The method used involved oven drying at $105 \pm 3^{\circ} \mathrm{C}$ for $24 \mathrm{~h}$. The results are expressed in percentage of seed weight. Dry matter accumulation was evaluated by weighing the tissue after drying at $105 \pm 3{ }^{\circ} \mathrm{C}$ for $24 \mathrm{~h}$. Each repetition was weighed separately on an analytical scale $(0.0001 \mathrm{~g})$, with the results expressed in grams, according to the recommendations of the Rules for Seed Analysis (BRASIL, 2009).

For the germination test, seeds were initially sterilised in a solution containing $0.125 \%$ of active chlorine plus Tween 20 (one drop of Tween 20 per $100 \mathrm{ml}$ of solution), before being constantly stirred for 10 minutes and then washed with distilled water five times. The test was set up with seeds placed within a roll of three sheets of "germitest" type paper $(28 \times 38 \mathrm{~cm})$ moistened with distilled water at a rate of three times the weight of the dry paper. Each roll was packed in a plastic bag to prevent drying of the substrate and possible contamination, and was then incubated in a germinator chamber (Eletrolab, Mod. EL202) at $25^{\circ} \mathrm{C}$ and continuous darkness until germination, i.e. $2 \mathrm{~mm}$ radicle protrusion. Daily evaluations were performed for 12 days until the completion of the test. Germination tests were conducted in a completely randomised design, using eight repetitions of 25 seeds (totalling 200 seeds) for each of the different stages of maturation. The parameters evaluated were: percentage of germination $(\mathrm{G})$, time to $50 \%$ of total germination $\left(\mathrm{T}_{50}\right)$, uniformity of germination $\left(\mathrm{U}_{8416}\right)$, area under the curve (AUC) and mean germination time (MGT). 
Total lipid extraction was performed with the Soxhlet procedure using $10 \mathrm{~g}$ of seeds (dry weight) and $300 \mathrm{ml}$ of hexane P.A. as an extraction solvent, with six to eight reflux cycles per hour. This stage lasted for eight hours, on average, and three replicates were conducted for each sample. The samples were previously oven dried, using the same procedure as was used for the determination of moisture content, and were then packed in filter paper cartridges for oil extraction. The quantification of total lipids was based on the weight of the samples (dry seeds) before and after lipid extraction, as calculated according to the formula described below, where data are expressed as percentages. Due to an insufficient amount of seeds in the early stages of development, lipid extraction was carried out only from the stage denominated "Green-E" in this study.

$$
\text { Oil content }(\%)=\frac{m_{a e}-m_{p e}}{m_{a e}} \times 100
$$

Where:

$\mathrm{m}_{\mathrm{ae}}=$ Weight of dry sample before extraction with solvent (g)

$\mathrm{m}_{\mathrm{pe}}=$ Weight of dry sample after extraction with solvent (g)

The results obtained in the germination test were analysed using the "GERMINATOR" software package (JOOSEN et al., 2010). The data were submitted to the Shapiro-Wilk normality test, and to compare means, we used the Student's $t$-test at $5 \%$ probability. In the other trials, the data were analysed with the statistical programme SISVAR (FERREIRA, 2000) and means were compared by a Tukey test at $5 \%$ probability.

\section{Results and Discussion}

The fruits of $J$. curcas were classified into six different stages of development based on their external morphological appearance, according to the colour of the exocarp (Figure 1), namely: green (exocarp predominantly green), green-yellowish (exocarp with pigmentation in transition from green to yellow), yellow (exocarp predominantly yellow), yellow-brownish (exocarp with yellow pigmentation in transition to brownish colour), brown-yellow (brown exocarp with residual yellow pigmentation) and brown-dry (exocarp predominantly brown, dry and starting dehiscence).

$J$. curcas fruits were also visually classified according to six maturation stages using the Munsell colour chart: green, beginning of yellow pigmentation, predominantly yellow, beginning of brown pigmentation, ripe, and dry beginning dehiscence (DRANSKI et al., 2010). Other authors found only four stages (PESSOA et al., 2012; SANTOS et al., 2012), including green, yellow, yellow with brown and dry. Silva et al. (2012) used five-stage rating, including yellow-green. CatzínYupit et al. (2014) verified a number of external morphological changes as indicators of physiological maturity for $J$. curcas fruits during development, coinciding with the exocarp turning yellow.

Figure 1. Classification of the fruits of $J$. curcas in different stages of maturation based on the colour of the exocarp. $\mathrm{Bar}=1 \mathrm{~cm}$.

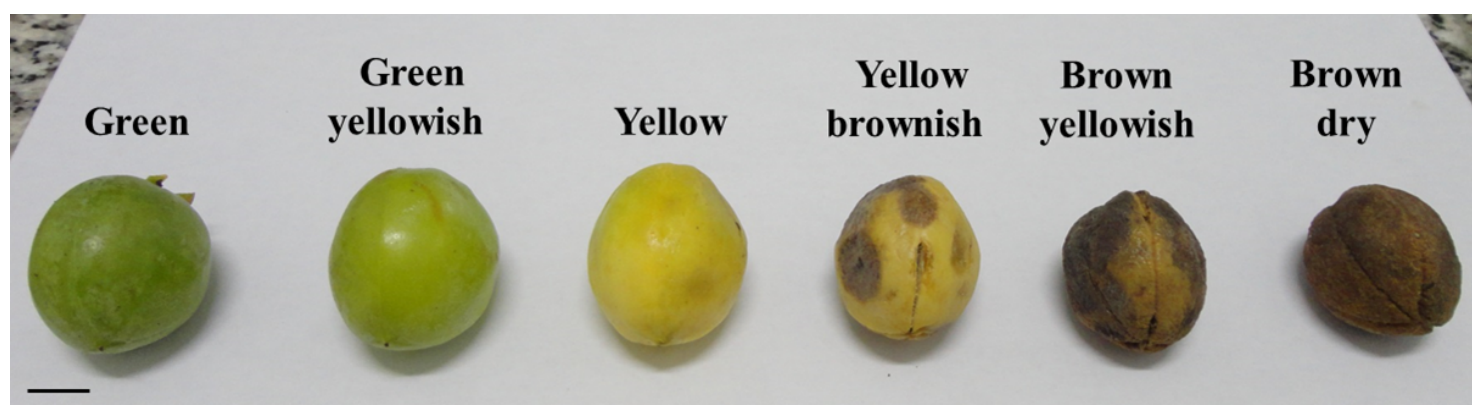


The seeds were classified according to 13 different maturation stages: green (divided into A, B, C, D, E, F, G, H), yellow-green, yellow, yellow-brownish, brown-yellowish, and brown-dry. As the seeds reach the green stage, the $J$. curcas fruits maintained the same external morphological appearance (green and large) for about four weeks. However, the seeds found within these fruits showed different stages of development. They were visually divided into eight classes according to the colour and appearance of the testa (exotesta and endotesta), A, B, C, D, E, F, G and H (Figure 2). Thus, it was not possible to identify the different stages of seed development based only on the colour and size of the green fruit.

Seeds from green-yellowish, yellow, yellowbrownish, brown-yellowish and brown-dry fruits were classified using the same naming used for the fruit containing them, and showed testa colours similar to the seeds classified as green-H found in green fruits (Figure 3). The seeds found in dry fruits had stiff, rather dry and hard testa and were classified as brown-dry. The caruncle, on the other hand, was whitish at all stages, except for the brown-dry stage.

Gradual changes in the colour of the seed testa were observed throughout the seed's development. Initially, the testa showed a translucent clear or whitish coloration, later turning to orange with darker coloration at the extremities (hilum and opposite side), which developed to a total blackening. At the final stage, they were black and shiny. In the green-A stage, the embryo had two small rudimentary cotyledons representative of a torpedo stage. In B to D-green seeds, embryos were in growing cotyledonary stages with a longitudinally elongating embryonic axis and growing cotyledons, whereas it was possible to distinguish the radicle/ hypocotyl and cotyledons (Figure 2).
At 25 DAA (days after anthesis), corresponding to stage green-E, Catzín-Yupit et al. (2014), found that the seed testa began to gain a rigid consistency and, at 35 DAA seeds presented a completely solid consistency, corresponding to stages green-E and green-yellowish in the present study. However, seeds with such aspects were observed in the present study only in the green-D and green-H stages, i.e. in earlier stages than described by those authors. Several authors who studied the maturation of $J$. Curcas seeds made no distinction between the seeds from green fruits (KAUSHIK, 2003; DRANSKI et al., 2010; PESSOA et al., 2012; SANTOS et al., 2012; SILVA et al., 2012). Rubio et al. (2013), on the other hand, classified these seeds according to only two stages, light and dark green. However, from the findings of the present study, it has become evident that there is a wide variation of maturation stages among seeds extracted from green fruits, hence the importance of this classification.

According to Silva et al. (2011), the fruits remain green until $55 \mathrm{DAA}$ and the changes from the final green to the dark brown stage occur in about 10 days, showing a rapid maturation phase. Changes in exocarp colour can be explained by physicochemical changes, among them chlorophyll degradation and the formation of other pigments that alter fruit colour (RAVEN et al., 2007).

The physiological maturity of seeds is usually accompanied by visible changes in external aspects, such as the fruit colour and the colour of the seeds themselves (SOUZA; LIMA, 1985; FIGLIOLIA, 1995). Thus, the colour of fruits and seeds can also be considered an important parameter in determining physiological maturity (CORVELLO et al., 1999; FOWLER; MARTINS, 2001). Harvest should occur during the proper stage of maturity, as immature fruits are of poor quality, present high water loss rates, and are therefore more susceptible to physiological disorders (AZZOLINI et al., 2004). 
Figure 2. Seeds of J. curcas in eight different stages of development found in fruits with green exocarp; A-completely translucent clear testa and embryo in the torpedo stage; $\mathbf{B}$ - predominantly orange-coloured exotesta and embryo in the young cotyledonary stage; $\mathbf{C}$ - Orange-coloured exotesta and endotesta with dark extremities and embryo in the intermediate cotyledonary stage; D - yellowish exotesta and completely dark endotesta and embryo in the final cotyledonary stage; $\mathbf{E}$ - exotesta that has a clear middle section, is slightly darker at the extremities and has completely dark endotesta; $\mathbf{F}$ - exotesta that has a light middle section, is strongly dark at the extremities, and the endotesta is completely dark; $\mathbf{G}$ - exotesta that has a narrow clear central stripe, is strongly dark at the extremities and the endotesta is completely dark; $\mathbf{H}$ - dark and fully formed testa. Arrows indicate the testa (exotesta plus endotesta) of the seeds.

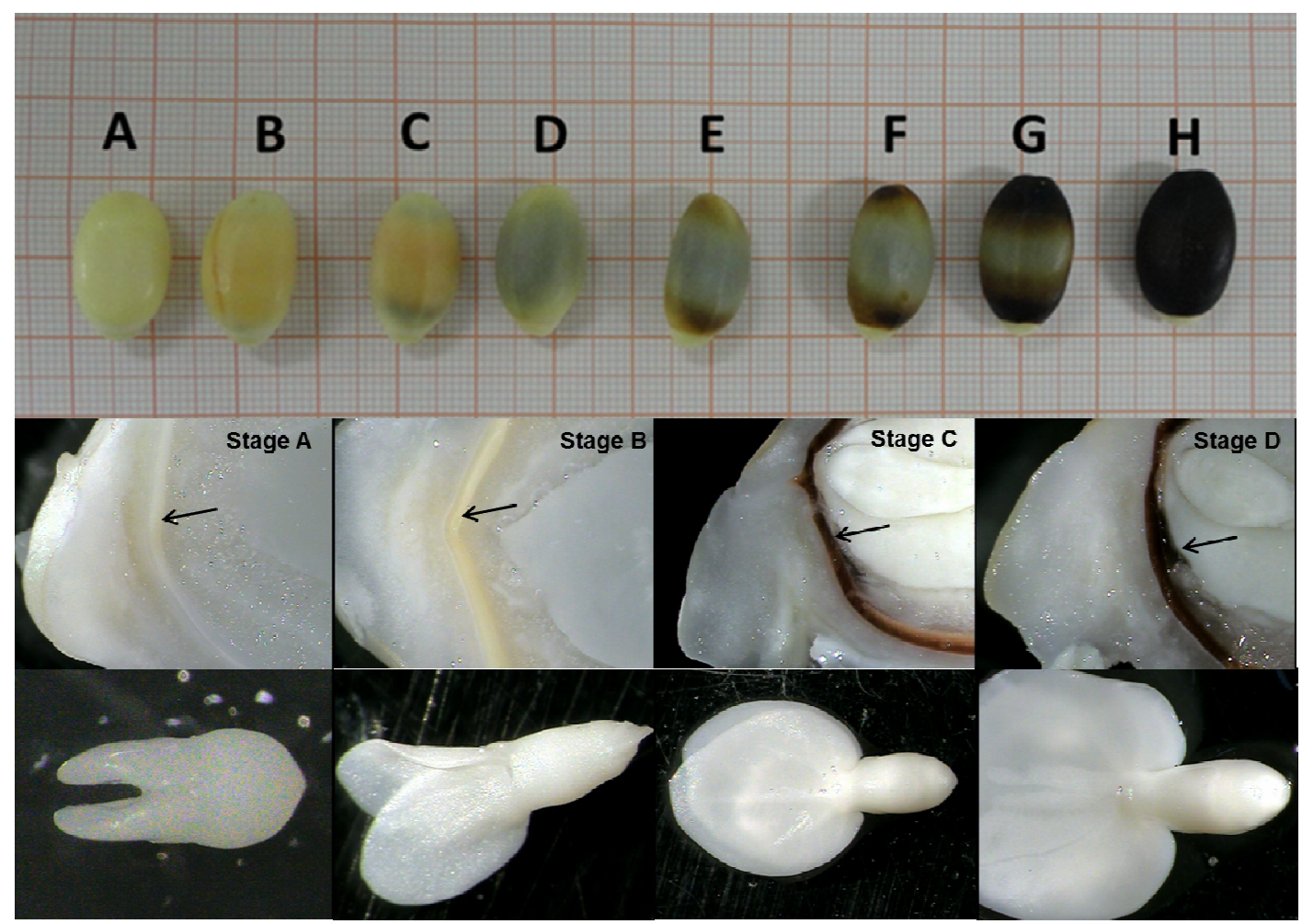

Figure 3. Visual appearance of $J$. curcas seeds found in fruits at different stages of maturation. (a) Green-yellowish; (b) Yellow-brownish; (c) Black mature dry seed. Bar $=0.5 \mathrm{~cm}$.
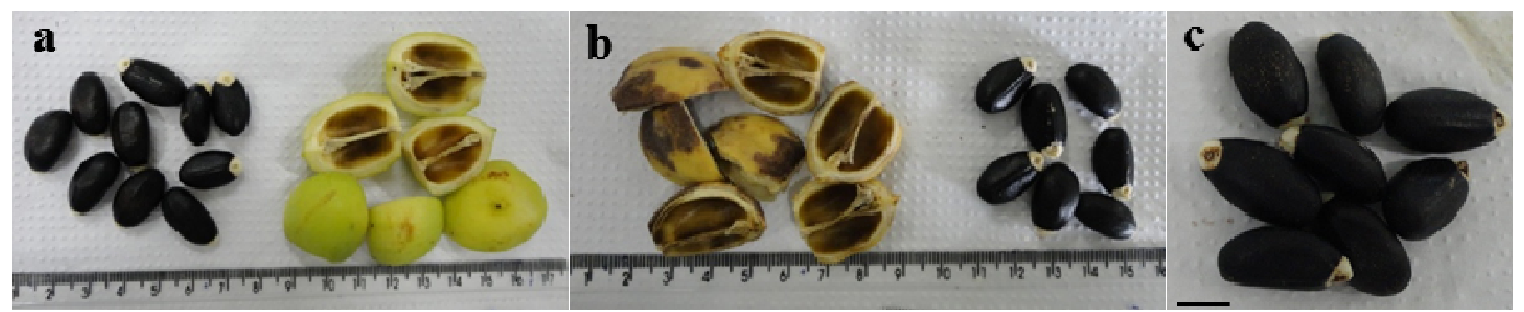
Studies with several species have related the physical characteristics (size, weight and moisture) and the morphological ones (colouring of fruits and seed testa) to different stages of maturation (LIN, 1988; LAGO et al., 1994; DIAS et al., 2001; FANAN et al., 2009; DRANSKI et al., 2010). The monitoring of these physical and physiological changes that occur during the development of fruits and seeds allows for the identification of a mature seed in the field, illustrating the moment it stops receiving nutrients from the mother plant, reaches physiological maturity and may therefore be harvested (SILVEIRA et al., 2002).

Over the maturation period, a significant reduction in the dimensions of the fruits of $J$. curcas was verified, beginning after the green-yellowish stage. Maximum values for the morphometric variables were observed in fruits with greenyellowish colouring and minimum values were observed in the brown-dry ones. Length and width varied from 30,8 to $27,2 \mathrm{~mm}$ and from 26,6 to 21,4 $\mathrm{mm}$, respectively. Green fruits presented lower mean values for length and width than did the other stages (Table 1). Unevenness in the developmental stages of the seeds found in these fruits, associated with the values for dry mass, moisture content, germination percentage and total lipid levels (Tables 2-5), indicates that the seeds and fruits are still growing at this stage as a result of the seed maturation processes (BEWLEY; BLACK, 2004).

Table 1. Morphometric variables (length and width) of the fruits of $J$. curcas in different stages of development and maturation.

\begin{tabular}{|c|c|c|}
\hline Developmental stage & Length (mm) & Width (mm) \\
\hline Green & $29,47 \quad a b$ & $25,88 \quad a b$ \\
\hline Green-yellowish & $30,76 \quad a$ & 26,63 a \\
\hline Yellow & $30,42 \quad a$ & $26,00 \mathrm{ab}$ \\
\hline Yellow-brownish & $29,25 \quad a b$ & $24,86 \quad b$ \\
\hline Brown-yellowish & $28,26 \quad b c$ & $23,12 \quad \mathrm{c}$ \\
\hline Brown-dry & $27,24 \quad \mathrm{c}$ & $21,44 \quad \mathrm{~d}$ \\
\hline Mean value & 29,23 & 24,66 \\
\hline $\mathrm{VC}(\%)$ & 2,54 & 2,30 \\
\hline
\end{tabular}

Mean values followed by the same letter in the column do not differ by $5 \%$ Tukey test.

The larger size of the green-yellowish $J$. curcas fruits has been reported (DRANSKI et al., 2010), as well as the decrease of the morphometric variables during the final stages of maturation (SANTOS et al., 2012). The fruit size reduction over the various assessed stages can be related to variations in moisture content (Table 3), which occur naturally during the maturation process of orthodox seeds as a result of dry matter accumulation (BEWLEY; BLACK, 2004). Water is the medium in which the nutrients are removed from the ground and transported to the photosynthetic organs of the plants, where they are transformed into photoassimilates and are then moved to the developing tissues, such as the fruits and seeds (TAIZ; ZEIGER, 2009). Thus, an initial increase in the dimensions of the seeds and fruits is common during the development process and is observed in various species, such as the Bixa orellana (AMARAL et al., 2001), Tamarindus indica (GURJÃO et al., 2006) and Apuleia leiocarpa (LOUREIRO et al., 2004). 
Table 2. Morphometric variables (length, width, thickness) of $J$. curcas seeds at different stages of development and maturation.

\begin{tabular}{|c|c|c|c|c|c|c|}
\hline \multirow{3}{*}{$\begin{array}{l}\text { Developmental stage } \\
\text { Green-C }\end{array}$} & \multicolumn{6}{|c|}{ Morphometric variables (mm) } \\
\hline & \multicolumn{2}{|c|}{ Length } & \multicolumn{2}{|c|}{ Width } & \multicolumn{2}{|c|}{ Thickness } \\
\hline & 20,18 & $\mathrm{a}$ & 11,36 & $\mathrm{a}$ & 9,23 & $\mathrm{a}$ \\
\hline Green-D & 18,86 & $\mathrm{fg}$ & 11,16 & $a b c$ & 8,35 & cde \\
\hline Green-E & 18,78 & $\mathrm{fg}$ & 10,94 & $\mathrm{~cd}$ & 8,23 & $\mathrm{e}$ \\
\hline Green-F & 19,10 & ef & 10,94 & $\mathrm{~cd}$ & 8,30 & cde \\
\hline Green-G & 19,68 & ef & 11,00 & bcd & 8,48 & bcd \\
\hline Green-H & 19,94 & $\mathrm{ab}$ & 11,09 & bcd & 8,53 & $\mathrm{bc}$ \\
\hline Green-yellowish & 19,19 & ef & 10,97 & $\mathrm{~cd}$ & 8,28 & de \\
\hline Yellow & 20,12 & $\mathrm{a}$ & 11,23 & $a b$ & 8,63 & $\mathrm{~b}$ \\
\hline Yellow-brownish & 19,49 & bcd & 11,08 & bcd & 8,49 & bcd \\
\hline Brown-yellowish & 19,52 & $\mathrm{ab}$ & 10,92 & $\mathrm{~d}$ & 8,60 & $\mathrm{~b}$ \\
\hline Brown-dry & 18,60 & $\mathrm{~g}$ & 10,86 & $\mathrm{~d}$ & 8,49 & bcd \\
\hline Mean value & 19,41 & & 11,05 & & 8,51 & \\
\hline $\mathrm{VC}(\%)$ & 0,88 & & 0,89 & & 1,08 & \\
\hline
\end{tabular}

Mean values followed by the same letter in the column do not differ by $5 \%$ Tukey test.

Table 3. Moisture content (\%) and dry mass (g) of J. curcas seeds at different stages of development and maturation.

\begin{tabular}{lccc}
\hline Developmental stage & Moisture content (\%) & Dry mass $(\mathbf{g})$ \\
\hline Green-C & $80,56 \mathrm{a}$ & 0,91 & $\mathrm{~h}$ \\
Green-D & $70,69 \mathrm{~b}$ & $1,38 \mathrm{~g}$ \\
Green-E & $65,92 \mathrm{c}$ & 1,60 & $\mathrm{fg}$ \\
Green-F & $62,35 \mathrm{~cd}$ & 1,83 ef \\
Green-G & $58,76 \mathrm{~d}$ & 2.07 & $\mathrm{de}$ \\
Green-H & $53,90 \mathrm{e}$ & $2,32 \mathrm{~cd}$ \\
Green-yellowish & $50,27 \mathrm{ef}$ & $2,60 \mathrm{bc}$ \\
Yellow & $46,63 \mathrm{fg}$ & $2,48 \mathrm{bc}$ \\
Yellow-brownish & $45,49 \mathrm{~g}$ & 2,77 & $\mathrm{~b}$ \\
Brown-yellowish & $43,28 \mathrm{~g}$ & $2,69 \mathrm{~b}$ \\
Brown-dry & $16,13 \mathrm{~h}$ & $4,12 \mathrm{a}$ \\
\hline Mean value & 54,00 & 2,25 & \\
\hline VC (\%) & 3,36 & 5,58 & \\
\hline
\end{tabular}

Mean values followed by the same letter in the column do not differ by $5 \%$ Tukey test.

Regarding the analyses of the morphometric dimensions, $J$. curcas seeds showed a decrease in length during the final stage of maturation (browndry). Significant variations in width and thickness were observed only between the first and the last two evaluated stages. Seeds in stages green-C and yellow had the largest length dimensions, while the dry ones had the smallest. Between the initial stage (green-C) and the final one (brown-dry), the seeds showed a mean variation from 20,2 to $18,6 \mathrm{~mm}$ in length, 11,4 to $10,9 \mathrm{~mm}$ in width, and 9,2 to $8,5 \mathrm{~mm}$ in thickness (Table 2).

During the transitions from the green-yellowish to yellow and the yellow-brownish to brownyellowish stages, no significant change in dry weight occurred (Table 3). Silva et al. (2012) found the same pattern for $J$. curcas seeds at different stages of maturation. However, Dranski et al. (2010) and 
Silva et al. (2011) found higher mean values for dry matter in fruits with brown colouring, suggesting the start of the disconnection of the fruit from the mother plant and beginning deterioration.

In this study, the seeds showed a significant decrease in moisture content from the initial stages until the end of development and maturation, ranging from $80,7 \%$ in seeds classified as green-C and extracted from green fruits, to $16,1 \%$ in browndry seeds (Table 3). A large variation in moisture content was observed in seeds found in green fruits, with a difference of $26,7 \%$ between the green- $\mathrm{C}$ and green-H stages. Furthermore, there was a substantial decline of about $27,2 \%$ in the moisture content of seeds from brown-yellowish to brown-dry.

In several studies regarding $J$. curcas seed maturation, moisture content values were similar to the ones verified in this study. In seeds from green and from brown-dry fruits, moisture contents of $88,8 \%$ and $10,74 \%$, respectively, were recorded (PESSOA et al., 2012). Rubio et al. (2013) found $11.06 \%$ humidity for dry fruit, as well. Silva et al. (2011) reported a decrease of 23,2\% from the penultimate (brown-yellowish) to the final stage (brown-dry), indicating this step as the end of the seed ripening process for this species.

The high moisture content found in early seed maturation is essential for the transport of photosynthesised products that are used as an energy source for metabolism by the developing seeds, and subsequently are stored as reserves to be used at the time of germination (CORVELLO et al., 1999; SANTOS et al., 2012). Xu et al. (2011) also verified an exponential increase in fresh weight during the early stages of $J$. curcas seed development and a stop in growth during the last stages, thereby initiating the process of desiccation with increased accumulation of lipids and other nutrients as a reserve. Therefore, some physical criteria assessed as a whole, such as morphometry, moisture content and dry matter, indicate the physiological maturity of this species' seeds (CROOKSTON; HILL, 1978).
Seeds extracted from the green fruits of the green-C to green-E stages did not germinate, and germination in the green-F stage was less than $1 \%$. This was due to the immaturity of the embryo during these stages, as seen in Figure 2. A maximum germination percentage of $86 \%$ was recorded for seeds extracted from green-yellowish fruits. From this stage onwards, there was a significant decrease in germination to $77 \%$ and $61 \%$ in yellow-brownish and brown-dry stages, respectively (Table 4). These stages correspond to the final period of desiccation, and the decrease in germination may be related to the acquisition of primary dormancy (HILHORST, 1995; BASKIN; BASKIN, 2004). J. curcas requires a postharvest period in order to improve germination (JØKER; JEPSEN, 2003). However, its germinability is inhibited simply by the presence of the endosperm, suggesting that this structure causes some degree of dormancy where the storage time appears to reduce this effect while regaining germinability (PAIVA NETO et al., 2014).

For the variables time to $50 \%$ of total germination $\left(\mathrm{T}_{50}\right)$ and mean germination time (GMT), the brown-dry seeds had the best performance (less time), while seeds in the green-G stadium showed the worst performance (longest time), with the most elevated mean values. In the other stages, these variables remained constant (Table 4).

Germination was more uniform $\left(\mathrm{U}_{8416}\right)$ in the green-H stage, while the lowest uniformity was found in both stages that had brownish colouring. The overall germinability, as measured by the area under the curve parameter (AUC), gradually increased over the maturation process, peaking from the yellow stage onwards and showing no significant differences until the brown-dry stage (Table 4). The decrease in AUC at this stage may also have resulted from the acquisition of dormancy, whereas seeds that are harvested later may suffer a decrease in physiological quality, as characterised by accelerated deterioration and reduced germination (MARCOS FILHO, 2005). 
Table 4. Percentage of germination $(\mathrm{G})$, time to $50 \%$ of total germination $\left(\mathrm{T}_{50}\right)$, mean germination time (MGT), uniformity of germination $\left(\mathrm{U}_{8416}\right)$ and area under the curve (AUC) of $J$. curcas seeds at different stages of development and maturation.

\begin{tabular}{|c|c|c|c|c|c|c|c|c|c|c|}
\hline \multirow{2}{*}{$\begin{array}{l}\text { Developmental } \\
\text { stage }\end{array}$} & \multicolumn{10}{|c|}{ Variables } \\
\hline & \multicolumn{2}{|c|}{ G(\%) } & \multicolumn{2}{|c|}{$\mathbf{T}_{50}(\mathrm{~h})$} & \multicolumn{2}{|c|}{ TMG (h) } & \multicolumn{2}{|l|}{$\mathrm{U}_{\text {g416 }}$ (h) } & \multicolumn{2}{|c|}{ AUC } \\
\hline Green-G & 47 & $\mathrm{~d}$ & 176,3 & $\mathrm{c}$ & 172,9 & $\mathrm{c}$ & 79,6 & $\mathrm{ab}$ & 0,1 & $\mathrm{~d}$ \\
\hline Green-H & 85 & $a b$ & 151,2 & $\mathrm{~b}$ & 151,1 & $\mathrm{~b}$ & 67,4 & $\mathrm{a}$ & 0,5 & $\mathrm{c}$ \\
\hline Green-yellowish & 86 & $\mathrm{a}$ & 153,0 & $\mathrm{~b}$ & 133,6 & $a b c$ & 89,1 & $a b c$ & 1,3 & $\mathrm{~b}$ \\
\hline Yellow & 81 & $\mathrm{ab}$ & 137,6 & $\mathrm{~b}$ & 134,6 & $\mathrm{a}$ & 106,4 & $\mathrm{bc}$ & 3,3 & $\mathrm{a}$ \\
\hline Yellow-brownish & 77 & $\mathrm{~b}$ & 142,0 & $\mathrm{~b}$ & 138,6 & $\mathrm{ab}$ & 105,2 & $\mathrm{c}$ & 2,7 & $\mathrm{a}$ \\
\hline Brown-yellowish & 62 & $\mathrm{~cd}$ & 141,4 & $\mathrm{~b}$ & 136,3 & $a b$ & 114,7 & $\mathrm{c}$ & 3,4 & $\mathrm{a}$ \\
\hline Brown-dry & 61 & $\mathrm{c}$ & 120,4 & $\mathrm{a}$ & 106,9 & $\mathrm{a}$ & 96,9 & $\mathrm{bc}$ & 4,7 & $\mathrm{a}$ \\
\hline Mean value & 71 & & 146,0 & & 139,1 & & 94,2 & & 2,3 & \\
\hline VC (\%) & 20,9 & & 11,7 & & 14,3 & & 17,6 & & 74,1 & \\
\hline
\end{tabular}

Mean values followed by the same letter in the column do not differ by $5 \%$ Tukey test.

Immature $J$. curcas seeds extracted from green fruits did not germinate and the maximum germination rate was observed only in dry seeds (DRANSKI et al., 2010; PESSOA et al., 2012). Other authors found the highest germination rates and germination speed in fruits with brown colour (SILVA et al., 2011, 2012). Kaushik (2003), however, observed the maximum percentage of germination in seeds extracted from yellow fruits.

The identification of the appropriate stage of maturity for seed collection at the proper time is of the utmost importance, especially for crops with uneven fructification and maturation, like in $J$. curcas. Different criteria, such as size, colour, moisture and lipid content, as well as germination aspects, have been used to establish the physiological maturity point of oil seed species and have proven to be efficient. Significant differences in the total lipid content could be observed during the development of $J$. curcas seeds (Table 5), with a $14 \%$ increase in these values when comparing the initial stages to the final ones. The highest percentages of total lipids were found in seeds from fruits with brownyellow colouring $(26,11 \%)$ and those from dry fruits (23,28\%).

Table 5. Total lipid content (\%) in J. curcas seeds at different stages of development and maturation.

\begin{tabular}{|c|c|}
\hline Developmental stage & Total lipid content (\%) \\
\hline Green-E & $9,27 \quad \mathrm{e}$ \\
\hline Green-F & 17,84 bcd \\
\hline Green-G & 17,78 bcd \\
\hline Green-H & $21,17 \quad a b c$ \\
\hline Green-yellowish & 11,88 be \\
\hline Yellow & $23,10 \quad a b$ \\
\hline Yellow-brownish & 14,88 cde \\
\hline Brown-yellowish & 26,11 a \\
\hline Brown-dry & $23,28 \quad a b$ \\
\hline Mean value & 18,44 \\
\hline $\mathrm{VC}(\%)$ & 7,08 \\
\hline
\end{tabular}

Mean values followed by the same letter in the column do not differ by $5 \%$ Tukey test. 
Variations in the percentages of lipids and other reserves are characteristic of the maturation process, because these values are translated in variations of fresh and dry weight of the seeds, which was verified in this study when assessing the moisture content and dry matter (Table 3). In this species, Santos et al. (2012) also found the maximum lipid content in $J$. curcas seeds from brown-yellowish and brown fruits, at 26,21 and 25,34\%, respectively. Annarao et al. (2008) found that the oil content was low in the initial stages and higher in the later stages, increasing from 0,3 to $24,9 \%$ (characterized by the authors as stages I-VI). They also found a small decrease in the percentage of oil in mature seeds, or stage VII $(24,4 \%)$, when compared to the preceding stages. Porwal et al. (2014) also reported a decrease in the percentage of lipids in mature seeds $(32 \%)$ compared to seeds extracted from green fruit (33\%) and seeds from brown and yellow fruits (34\%).

The maximum content of lipids found in this study may be considered relatively low when compared to data reported in the literature. Lipid content in J. curcas seeds was reported to be as high as $40 \%$ (SOUZA et al., 2009), while the highest levels of total lipids in $J$. curcas seeds cultivated in the state of Maranhão was about 31,6\%. In this case, the calculation was based on the wet weight (PENHA et al., 2007).

According to Santos et al. (2012), the accumulation, as well as the composition, of lipids stored in seeds depends on genetic factors and field conditions during maturation. According to Teixeira (1987), these differences may vary depending on location and cultural practices. Teixeira recorded variations from $23 \%$ to $34 \%$ in the total lipid content for $J$. curcas seeds. Changes in the hydric regime during the period of maturation may also explain the variations found in the total lipid content between seeds from different accessions, since they directly interfere in biomass accumulation. From another angle, data published in the literature show that higher total lipid content values are achieved with the extraction of albumen lipids, as reported by
Penha et al. (2007), with values of $31,62 \%$ in whole seeds and $66 \%$ in the albumen.

From these results, it can be concluded that in the green fruits of $J$. curcas, it is not possible to establish the stage of development of the seeds based solely on the colour of the exocarp, making it necessary to perform morphophysiological analyses as a whole. The parameters that best determined the physiological maturation of the seeds of this species were: smaller dimensions in length and width, maximum dry matter accumulation, lower moisture content, and higher lipid content. Therefore, seeds reached physiological maturity when they were brown coloured and the fruit was dry, indicating that this stage was the best period for harvesting.

\section{Acknowledgements}

We thank CAPES and CNPq for granting the $\mathrm{PhD}$ and Scientific Initiation scholarships. We also thank the Company for Agricultural Development of Bahia (EBDA), for allowing the harvest of seeds in their Experiment Station. Finally, we acknowledge the post-graduate program in Plant Genetic Resources at the State University of Feira de Santana, and PETROBRAS (Cooperation agreement $\mathrm{n}^{\circ}$ 0050.0062805.10.9) and CAPESPNPD (Project $n^{\circ} 00000.059047 / 2010$ ) for funding this research.

\section{References}

ACHTEN, W. M.; NIELSEN, L. R.; AERTS, R.; LENGKEEK, A. G.; KJAER, E. D.; TRABUCCO, A.; HANSEN, J. K.; MAES, W. H.; GRAUDAL, L.; AKINNIFESI, F. K.; MUYS, M. Towards domestication of Jatropha curcas. Biofuels, London, v. 1, n. 1, p. 91107, 2010.

AMARAL, L. I. V.; PEREIRA, M. F. D. A.; CORTELAZZO, A. L. Formação das substâncias de reserva durante o desenvolvimento de sementes de urucum (Bixaorellana L. - Bixaceae). Acta Botânica Brasílica, Feira de Santana, v. 15, n. 1, p. 125-132, 2001.

ANNARAO, S.; SIDHU, O. P.; ROY, R.; TULI, R.; KHETRAPAL, C. L. Lipid profiling of developing 
Jatropha curcas L. seeds using 1H NMR spectroscopy. Bioresource Technology, Oxford, v. 99, n. 18, p. 90329035, 2008.

AZZOLINI, M.; JACOMINO, A. P.; BRON, I. U. Índices para avaliar qualidade pós-colheita de goiabas em diferentes estádios de maturação. Pesquisa Agropecuária Brasileira, Brasília, v. 39, n. 2, p. 139-145, 2004.

BASKIN, J. M.; BASKIN, C. C. A classification system for seed dormancy. Seed Science Research, Cambridge, v. 14, n. 1, p. 1-16, 2004.

BEWLEY, J. D.; BLACK, M. Seeds: physiology of development and germination. New York: Plenum, 1994. $445 \mathrm{p}$.

BRASIL. Ministério da Agricultura, Pecuária e Abastecimento. Regras para análise de sementes. Secretaria de Defesa Agropecuária. Brasília: Mapa/ACS, 2009. $395 \mathrm{p}$.

CARVALHO, N. M.; NAKAGAWA, J. Sementes: ciência, tecnologia e produção. 4. ed. Jaboticabal: Funep, 2000. 588 p.

CASTRO, R. D. de; HILHORST, H. W. M. Embebição e reativação do metabolismo. In: FERREIRA, A.G.; BORGHETTI, F. (ED.). Germinação. Do básico ao aplicado. Porto Alegre: Artmed. 2004, p. 149-162.

CATZÍN-YUPIT, C. N.; RAMIREZ-MORILLO, I. M.; POOL, F. A. B.; LOYOLA-VARGAS, V. M. Ontogenic development and structure of the embryo, seed, and fruit of Jatropha curcas L. (Euphorbiaceae). South African Journal of Botany, Matieland, v. 93, n. 1, p. 1-8, 2014.

CORTESÃO, M. Culturas tropicais: plantas oleaginosas. Lisboa: Clássica, 1956. $231 \mathrm{p}$.

CORVELlO, W. B. V.; VILELlA, F. A.; NEDEL, J. L.; PESKE, S. T. Época de colheita e armazenamento de sementes de cedro (Cedrella Fissilis Vell.). Revista Brasileira de Sementes, Londrina, v. 21, n. 2, p. 28-34, 1999.

CROOKSTON, R. K.; HILL, D. S. A visual indicator of the physiological maturity of soybean seed. Crop Science, Madison, v. 18, n. 5, p. 867-870, 1978.

DE RON, A. M.; CASQUERO, P. A.; GONZALEZ, A. M.; SANTALLA, M. Environmental and genotypic effects on pod characteristics related to common bean quality. Journal of Agronomy and Crop Science, Braunschweig, v. 190, n. 4, p. 248-255, 2004.

DELOUCHE, J. C. Environmental effects on seed development and seed quality. Hort Science, Alexandria, v. 15, n. 6, p. $775-780,1980$.
DIAS, D. C. F. Maturação de sementes. Seed News, Pelotas, v. 5, n. 6, p. 22-24, 2001.

DRANSKI, J. A. L.; PINTO JÚNIOR, A. S.; STEINER, F.; ZOZ, T.; MALAVASI, U. C.; MALAVASI, M. M.; GUIMARÃES, V. F. Physiological maturity of seeds and colorimetry of fruits of Jatropha curcas L. Revista Brasileira de Sementes, Londrina, v. 32, n. 4, p. 158-165, 2010.

DRUMMOND, M. A.; ARRUDA, F. P.; ANJOS, J. $\mathrm{B}$ dos. Pinhão-manso - Jatropha curcas L. Petrolina: Embrapa Semi-Árido, 2008. 15 p. (Embrapa Semi-Árido. Documentos, 212).

EGLI, D. B. Seed Biology and yeld of grain crops. New York: CAB International, 1998. 178 p.

FANAN, S.; MEDINA, P. F.; CAMARGO, M. B. P.; RAMOS, N. P. Influência da colheita e do armazenamento na qualidade fisiológica de sementes de mamona. Revista Brasileira de Sementes, Londrina, v. 31, n. 1, p. 150-159, 2009.

FERREIRA, D. F. Sistema SISVAR para análises estatísticas: manual de orientação. Lavras: Universidade Federal de Lavras, Departamento de Ciências Exatas, 2000. $66 \mathrm{p}$.

FIGLIOLIA, M. B. Colheita de sementes. In: SILVA, A.; PIÑARODRIGUES, F. C. M.; FIGLIOLIA, M. B. Manual técnico de sementes florestais. São Paulo: Instituto Florestal, 1995. p. 1-12. (Série Registros, 14).

FOWLER, J. A. P.; MARTINS, E. G. Coleta de sementes. In: FOWLER, J. A. P.; MARTINS, E. G. (Ed.). Manejo de sementes de espécies florestais. Colombo: EMBRAPA Florestas, 2001. v. 1, p. 9-13. (Documentos, 58).

GURJÃO, K. C. de O.; BRUNO, R. de L. A.; ALMEIDA, F. de A. C.; PEREIRA, W. E.; BRUNO, G. B. Desenvolvimento de frutos e sementes de tamarindo. Revista Brasileira de Fruticultura, Jaboticabal, v. 28, n. 3, p. 351-354, 2006.

HILHORST, H. W. M. A critical update on seed dormancy. I. Primary dormancy. Seed Science Research, Cambridge, v. 5, n. 2, p. 61-73, 1995.

JØKER, D.; JEPSEN, J. Jatropha curcas L. Humleback: Seed Leaflet, 2003. n. 83, p. 1-2. Available at: <http:// curis.ku.dk/ws/files/20648145/jatropha_curcas_83.pdf`. Accessed at: 23 nov. 2014.

JONGSCHAAP, R. E. E.; CORRE, W. J.; BINDRABAN, P. S.; BRANDENBURG, W. A. Claims and facts on Jatropha curcas L. Global Jatropha curcas evaluation, breeding and propagation program. Plant Research International, Wageningen, v. 1, n. 158, p. 1-42, 2007. 
JOOSEN, R. V. L.; KODDE, J.; WILLEMS, L. A. J.; LIGTERINK, W.; VAN DER PLAS, L. H. W.; HILHORST, H. W. M. GERMINATOR: a software package for high-throughput scoring and curve fitting of Arabidopsis seed germination. The Plant Journal, Oxford, v. 1, n. 62, p. 148-159, 2010.

KAUSHIK, N. Effect of capsule maturity on germination and seedling vigour in Jatropha curcas. Seed Science and Technology, Zürich, v. 31, n. 2, p. 449-454, 2003.

LAGO, A. A.; SAVY FILHO, A.; BANZATTO, N. V.; CAMARGO, O. B. A. Maturação e produção de sementes do gergelim 'iac-ouro'. Revista Brasileira de Sementes, Londrina, v. 16, n. 2, p. 134-137, 1994.

LIN, S. S. Efeito do tamanho e maturidade sobre a viabilidade, germinação e vigor do fruto de palmiteiro. Revista Brasileira de Sementes, Londrina, v. 8, n. 1, p. 57-66, 1988.

LOUREIRO, M. B.; GONÇALVES, R.; ROSSETTO, C. A.V. Avaliação do efeito do tamanho de sementes na germinação e no vigor de garapa (Apuleialeiocarpa (Vog.) Macbr.). Revista da Universidade Rural, Seropédica, v. 24, n. 1, p. 73-77, 2004.

MARCOS FILHO, J. Fisiologia das sementes de plantas cultivadas. Piracicaba: Fealq, v. 12, 2005. 495 p.

MICHELANGELI, J. A. C.; BHAKTA, M.; GEZAN, S. A.; BOOT, K. J.; VALLEJOS, C. E. From flower to seed: identifying phenological markers and reliable growth functions to model reproductive development in the common bean (Phaseolus vulgaris L.). Plant, Cell and Environment, Rockville, v. 36, n. 11, p. 2046-20, 2013.

OPENSHAW, K. A review of Jatropha curcas: an oil plant of unfulfilled promise. Biomass and Bioenergy, Oxford, v. 19, n. 1, p. 1-15, 2000.

PAIVA NETO, V. B.; PRANDO, F. P.; RODRIGUES, L. A.; ZUFFO, M. C. R.; LIMA, S. F. Ação inibitória do endosperma na germinação in vitro de embrião zigótico de pinhão manso. Ciência Rural, Santa Maria, v. 44, n. 3, p. 433-438, 2014.

PEIXOTO, A. R. Plantas oleaginosas arbóreas. São Paulo: Nobel, 1973. 284 p.

PENHA, M. da N. C.; SILVA, M. D. P.; MENDONÇA, K. K. M.; BRANDÃO, K. S. R.; MACIEL, A. P.; SILVA, F. C. Caracterização físico-química da semente e óleo de pinhão manso (Jatropha curcas) cultivado no Maranhão. In: CONGRESSO DA REDE BRASILEIRA DE TECNOLOGIA DE BIODIESEL, 2., 2007, Brasília. Anais. Brasília: MCT/ABIPTI, 2007. p. 1-6.
PESSOA, A. M. S.; MANN, R. S.; SANTOS, A. G.; RIBEIRO, M. L. F. Influência de maturação de frutos na germinação, vigor e teor de óleo de sementes de pinhãomanso (Jatropha curcas L.). Scientia Plena, Aracajú, v. 8, n. 7, p. 1-11, 2012.

PORWAL, J.; BEHRA, B.; PONNEKANTI, N.; BANGWAL, D.; KAUL, S. An integrated analytical approach for the compositional evaluation of different stages of fully ripened Jatropha curcas seed oil. European Journal of Lipid Science and Technology, Weinheim, v. 117, n. 3, p. 398-405, 2014.

RAVEN, P. H.; EVERT, R. F.; EICHHORN, S. E. Biologia vegetal. 7. ed. Rio de Janeiro: Guanabara Koogan, 2007. $728 \mathrm{p}$.

RUBIO, F.; MENEGHEL, A. P.; GOMES, L. F. S.; MALAVASI, M. M. Estádios de maturação do fruto no desempenho germinativo e teor de óleo de sementes de Jatropha curcas Linn. Semina: Ciências Agrárias, Londrina, v. 34, n. 2, p. 663-668, 2013.

SANTOS, S.; MARTINS, M.; AGUILAR, P. Acúmulo de matéria seca e óleo nas sementes de pinhão manso e qualidade do óleo extraído. Revista Brasileira de Engenharia Agrícola e Ambiental, Campina Grande, v. 16, n. 2, p. 209-215, 2012.

SATURNINO, H. M.; PACHECO, D. D.; KAKIDA, J.; TOMINAGA, N.; GONÇALVES, N. P. Cultura do Pinhão manso (Jatropha curcas L.). Produção de oleaginosas para biodiesel. Informe Agropecuário, Belo Horizonte, v. 26, n. 229, p. 44-74, 2005.

SILVA, L. J.; DIAS, C. F. S.; MILAGRES, C. C.; DIAS, L. A. S. Relationship between fruit maturation stage and physiological quality of physic nut (Jatropha curcas L.). Ciência e Agrotecnologia, Lavras, v. 36, n. 1, p. 39-44, 2012.

SILVA, M. B. R.; FERNANDES, P. D.; DANTAS NETO, J.; NERY, A. R. Crescimento e produção do pinhãomanso irrigado com água residuária sob condições de estresse hídrico. Revista Brasileira de Engenharia Agrícola e Ambiental, Campina Grande, v. 15, n. 6, p. 261-269, 2011.

SILVEIRA, M. A. M.; VILLELA, F. A.; TILLMMANN, M. A. A. Maturação Fisiológica de sementes de Calêlndula (Calendula officinalis L.). Revista Brasileira de Sementes, Londrina, v. 24, n. 2, p. 31-37, 2002.

SOUZA, A. D. V. de; FAVARO, S. P.; ÍTAVO, L. C. V.; ROSCOE, R. Caracterização química de sementes e tortas de pinhão manso, nabo forrageiro e crambe. Pesquisa Agropecuária. Brasileira, Brasília, v. 44, n. 10, p. 1328-1335, 2009. 
SOUZA, S. M.; LIMA, P. C. F. Maturação de sementes de angico (Anadenanthera macrocarpa (Benth.) Brenan). Revista Brasileira de Sementes, Brasília, v. 7, n. 2, p. 9399, 1985.

TAIZ, L.; ZEIGER, E. Fisiologia vegetal. 4. ed. Porto Alegre: Artmed, 2009. 819 p.
TEIXEIRA, J. P. Teor e composição do óleo de sementes Jatropha Spp. Revista Bragantia, Campinas, v. 46, n. 1, p. 151-157, 1987.

XU, R.; WANG, R.; LIU, A. Expression profiles of genes involved in fatty acid and triacylglycerol synthesis in developing seeds of Jatropha (Jatropha curcas L.). Biomass and Bioenergy, Oxford, v. 35, n. 5, p. 16831692, 2011. 